\title{
RECOVERY OF THIRD-STAGE LARVAE OF ANGUILLICOLA CRASSUS (NEMATODA : DRACUNCULOIDEA) FROM THE FLESH OF FISHES : ASSESSMENT OF A DIGESTIVE MEDIUM AS A TOOL FOR THE STUDY OF FISH PARATENIC HOSTS.
}

\author{
A. AGOULON (1), G. BLANC ${ }^{*}(2)$, H. LE BRIS (2) and A. MARCHAND (1)
}

(1) Laboratoire de Parasitologie, Maladies Parasitaires et Zoologie appliquée, Ecole Nationale Vétérinaire, Atlanpole - La Chantrerie, B.P. 40706, 44307 Nantes Cedex 03, France.

(2) Laboratoire d'Aquaculture et Pathologie Aquacole, Ecole Nationale Vétérinaire, Atlanpole - La Chantrerie, B.P. 40706, 44307 Nantes Cedex 03, France.

\section{ABSTRACT}

The purpose of this study was to recover third-stage larvae (L3) of Anguillicola crassus alive from the flesh of fishes. Different digestive media have been tested on eel flesh for their efficiency and on living infective third-stage larvae for their harmlessness.

The results were :

(1) Long-term survival of the L3 larvae was low, but their morphological features were recognizable in each digestion runs.

(2) Pepsin concentrations between 2.5 and $40 \mathrm{~g} / \mathrm{l}$ proved to be without influence on the short-term (2-4 hours) survival of the L3 larvae of $A$. crassus. The digestion of the eel flesh was more advanced with the most concentrated media, when applied for 12 hours.

(3) L3 larvae survived longer at $\mathrm{pH} 1.8$ than 1.5, and digestion appeared to be faster at the upper $\mathrm{pH}$ level.

(4) L3 larvae survival was much longer at $20^{\circ} \mathrm{C}$ than at $30^{\circ} \mathrm{C}$, but efficiency of the digestion process was poor at the lower temperature.

For epidemiological studies, the optimal factors combination has been established at pepsin concentration : $10 \mathrm{~g} / \mathrm{l}, \mathrm{pH}: 1.8$ and temperature : $20-22^{\circ} \mathrm{C}$, particularly when quantitative recovery of $L 3$ larvae and work efficiency were taken into account.

Key-words : Nematoda, Anguillicola crassus, fish, paratenic host, infective thirdstage larvae, pepsin.

\footnotetext{
* Corresponding author.

Article available at http://www.kmae-journal.org or http://dx.doi.org/10.1051/kmae:2001005
} 


\section{EXTRACTION DE LARVES DE TROISIÈME STADE D'ANGUILLICOLA CRASSUS (NEMATODA : DRACUNCULOIDEA) DANS LA CHAIR DE POISSONS : MISE AU POINT D'UNE MÉTHODE PAR DIGESTION POUR L'ÉTUDE DU PORTAGE PARASITAIRE PAR LES POISSONS HÔTES PARATÉNIQUES.}

\section{RÉSUMÉ}

Le but de cette étude était de récupérer les larves de troisième stade (L3) d'Anguillicola crassus au sein de la chair de différents poissons. Neuf milieux de digestion ont été testés sur de la chair d'anguille, pour évaluer leur efficacité lytique. Ces mêmes milieux ont été testés sur des larves L3 vivantes d' $A$. crassus pour apprécier leur innocuité sur le parasite. Les résultats sont les suivants :

(1) La survie à long terme des larves L3 a été limitée, mais leur intégrité anatomique n'a pas été altérée, de sorte qu'elles sont restées identifiables dans chaque milieu testé.

(2) Aucune différence de survie à court terme (2-4 heures) n'a été constatée sur les larves selon la concentration en pepsine (2,5 ou $40 \mathrm{~g} / \mathrm{l})$. La concentration la plus élevée en pepsine a assuré une digestion plus poussée de la chair d'anguille après 12 heures de contact.

(3) Les larves L3 ont survécu plus longtemps à pH 1,8 qu'à pH 1,5. La digestion de la chair a été plus rapide à $\mathrm{pH} 1,8$.

(4) Les larves $\mathrm{L} 3$ ont survécu beaucoup plus longtemps à $20^{\circ} \mathrm{C}$ qu'à $30^{\circ} \mathrm{C}$, mais l'efficacité de la digestion à $20^{\circ} \mathrm{C}$ était limitée.

Pour l'application pratique dans un contexte d'enquête épidémiologique, un compromis économique a du être trouvé entre, d'une part, une bonne digestion des chairs pour une récupération importante de larves L3 et, d'autre part, une bonne intégrité des larves afin de pouvoir les identifier. Les paramètres optimaux suivants sont préconisés : concentration en pepsine $=10 \mathrm{~g} / \mathrm{l} ; \mathrm{pH}=1,8 ;$ température $=20-22^{\circ} \mathrm{C}$. pepsine

Mots-clés : Nematoda, Anguillicola crassus, poisson, hôte paraténique, larve L3,

\section{INTRODUCTION}

Enzymatic digestion is a common method to recover parasitic Nematode larvae in tissues from host species : mammals (SCHWARTZ, 1939 ; SPRENT, 1952 ; HERLICH, 1956 ; CIORDIA et al., 1957 ; REINECKE and BROOKER, 1972 ; REINEMEYER et HERD, 1986 ; VIGNAU et al., 1997), reptiles (BALLANTYNE et SAMUEL, 1984), gastropods (PLATT, 1989) and fishes (STERN et al., 1958 ; SMITH et WOOTTEN, 1975 ; HUANG, 1988 ; DEARDORF et THROM, 1988 ; DEARDORFF et KENT, 1989 ; ADAMS et al., 1999).

Current techniques rely on a sparing digestion : the cuticle of nematodes, containing keratin (CHITWOOD, 1936 ; BIRD, 1957 ; POLITZ et PHILIPP, 1992), is more resistant to enzymatic attack than the host tissues. 
In order to study the quantitative role of potential paratenic hosts in the life cycle of Anguillicola crassus (Nematoda : Dracunculoidea), the parasitic swimbladder-nematode of the eel, we planned to withdraw its third-stage larvae (L3) from the flesh and viscera of different fish species, starting with the eel in this study.

According to literature data (MINISTRY OF AGRICULTURE, FISHERIES AND FOOD, UK, 1971 ; GRABER et PERROTIN, 1983 ; GILDBERG, 1988 ; DE CHARLEROY et al., 1989 ; KENNEDY et FITCH, 1990), pepsin concentration, pH and temperature are the main factors involved in the enzymatic processes. DE CHARLEROY et al. (1989), KENNEDY et FITCH (1990) and THIBAUT (1993) have pointed out that the survival of second-stage larvae (L2) of $A$. crassus were temperature and $\mathrm{pH}$ dependant. These results were extrapolated to the infective L3 larval stage.

The purpose of this study was to determine optimal conditions for nematode larval recovery without compromising the viability of the parasitic larvae. The method employed should also permit quantitative recovery of larvae from infected fish and must therefore perform a complete digestion of the flesh of the fish. Digestion was tested on eel flesh in this study.

\section{MATERIALS AND METHODS}

\section{Provision of biological test material for digestion trials}

Cyclopid Copepods were used to obtain L3 larvae of $A$. crassus from L2 larvae by experimental infections of various species as outlined by PETTER et al. (1989). Copepods were sampled in the Erdre River (Nantes area, France) with a $125 \mu \mathrm{m}$-mesh net. Infections of these Copepods were performed in 10 I glass bottles at a ratio of 20 hatched $A$. crassus L2 larvae per Copepod. The free L2 larvae, recovered either by dissecting the eel swimbladder or the mature $A$. crassus females, were counted with a McMaster cell. After 10 to 15 days of incubation at $22^{\circ} \mathrm{C}$, most of the L2 larvae ingested by Copepods moulted into the L3 stage. These infective stages were then set free from the Copepod host and submitted to digestion and survival tests.

Eels were netted in the lake Grandlieu, $20 \mathrm{~km}$ south-west of Nantes and kept alive and unfed for 2 to 3 days at ambient temperature in $120 \mathrm{I}$ glass aquaria supplied with chlorine-free tap water, including $6 \mathrm{~g} / \mathrm{l}$ sodium chloride. Initial ionic characteristics of the water were : $\mathrm{Ca}^{2+}=40 \mathrm{ppm} ; \mathrm{NO}_{3}{ }^{-}=20 \mathrm{ppm} ; \mathrm{NO}_{2}^{-}<0.05 \mathrm{ppm} ; \mathrm{NH}_{4}{ }^{+}=0.4 \mathrm{ppm}$. The flesh of these eels was used for digestion experiments.

\section{Experimental design and chemicals}

The chemicals employed as stock solution were pepsin Merck $2500 \mathrm{U} . \mathrm{FIP} / \mathrm{g}$ (France), concentrated hydrochloric acid $(\mathrm{HCl})$ Panréac (Italy) and sodium chloride ( $\mathrm{NaCl}$ ) Labogros (France).

Two biological variates were taken into account : survival time of the L3 larvae and eel flesh digestion efficiency.

The effects of the involved three main factors (enzyme concentration, $\mathrm{pH}$, temperature) have been studied through a complete $2^{3}$ factorial design (GOUPY, 1988). The factorial design matrix is displayed in Table 1. Coordinates of an additional mid-point experiment were : enzyme concentration $=21.25 \mathrm{~g} / \mathrm{l}, \mathrm{pH}=1.65$; temperature $=25^{\circ} \mathrm{C}$. 
Concerning the survival time of L3 larvae, each of the nine runs (see Table 1) started with 30 alive L3 larvae. The dead and surviving larvae were counted every 2 hours during 12 hours under a stereo-microscope. L3 larvae were counted as dead when motionless under a needle stimulation.

The same factorial design was applied to the eel flesh digestion efficiency : ratio of the final weight of the exposed eel body section versus initial weight after 12 hours in the digestive media. Skinned proximal caudal parts of the eel flesh were used and prepared for three treatments to study the mode of enzymatic digestion : (1) a small piece of 2-3 $\mathrm{g}$ with transversal cuts and two longitudinal cuts reaching the vertebral axis ; (2) a small piece of similar weight $(2-3 \mathrm{~g})$ without any cuts ; (3) a larger piece of about 5-6 g with seven transversal cuts and two deep longitudinal cuts (Fig.1). A ratio of $4 \mathrm{ml}$ of digestive medium per gram of eel flesh was used and each of the three types of sections was submitted to the nine separate experiments (see Table 1).

Table 1

Experimental design for the survival tests of Anguillicola crassus L3 larvae under various combination factors of a digestive medium.

Tableau 1

Protocole expérimental pour les tests de survie des larves L3 d'Anguillicola crassus selon la combinaison de différents facteurs du milieu de digestion.

\begin{tabular}{|ccc|}
\hline & lower margin & upper margin \\
pepsin concentration & $-1: 2.5 \mathrm{~g} / \mathrm{l}$ & $+1: 40 \mathrm{~g} / \mathrm{l}$ \\
$\mathbf{p H}$ & $-1: 1.5$ & $+1: 1.8$ \\
temperature & $-1: 20^{\circ} \mathrm{C}$ & $+1: 30^{\circ} \mathrm{C}$ \\
\hline
\end{tabular}

\begin{tabular}{|c|c|c|c|}
\cline { 2 - 4 } \multicolumn{1}{c|}{} & $\begin{array}{c}\text { pepsin } \\
\text { concentration }\end{array}$ & pH & temperature \\
\hline Run 1 & -1 & -1 & -1 \\
\hline Run 2 & +1 & -1 & -1 \\
\hline Run 3 & -1 & +1 & -1 \\
\hline Run 4 & +1 & +1 & -1 \\
\hline Run 5 & -1 & -1 & +1 \\
\hline Run 6 & +1 & -1 & +1 \\
\hline Run 7 & -1 & +1 & +1 \\
\hline Run 8 & +1 & +1 & +1 \\
\hline Mid point & 0 & 0 & 0 \\
\hline
\end{tabular}



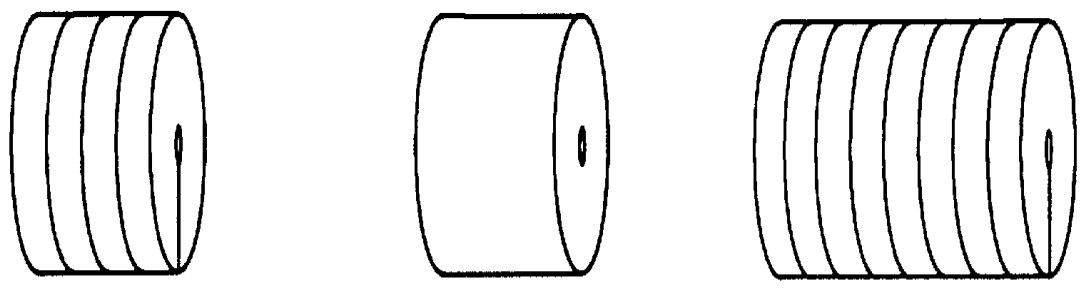

\section{Figure 1}

Sections of eel-flesh.

\section{Figure 1}

Sections de la chair de l'anguille.

\section{Statistical analysis}

Factors main effects and interactions were calculated as described in GOUPY (1988). Survival tables were set up according to the product-limit method of KAPLANMEÏER and compared with the Logrank test using an approximation of the MANTEL formula ( In LAPLANCHE et al., 1987).

\section{RESULTS}

\section{Larval survival}

Considering the mid-point run (see Tables 1 and 2), the responses were not linearly related to the factors under screening. Because of the general symmetry of the design, the effect of one factor could be calculated if the other factors remained constant.

After 12 hours in any of the digestive media, the results were similar, most L3 larvae being dead. However, in all runs the L3 larvae were easily recognizable even after 12 hours in the digestive media and, furthermore, the morphological features, internal structure, body lengths and widths were preserved.

According to data in Figure 2 and Table 2, the main effects of the factors were calculated for 2 and 4 hours survival rates (Tables 3 and 4 ). In both cases, the pepsin concentration effect was not significant at $5 \%$ (FISHER test) when pH and temperature were influent. The $\mathrm{L} 3$ larvae survival was favoured at $\mathrm{pH} 1.8$ and $20^{\circ} \mathrm{C}$. 
Table 2

Survival of L3 A. crassus in different media.

L: Living L3 larvae, D: Dead L3 larvae

Tableau 2

Survie des larves L3 d'Anguillicola crassus dans différents milieux de digestion.

L : Larves L3 vivantes, D : Larves L3 mortes

\begin{tabular}{|c|c|c|c|c|c|c|c|}
\hline & $\mathrm{Oh}$ & $2 \mathrm{~h}$ & $4 h$ & $6 \mathrm{~h}$ & $8 h$ & $10 \mathrm{~h}$ & $12 \mathrm{~h}$ \\
\hline Run 1 & $30 \mathrm{~L}$ & $\begin{array}{l}17 \mathrm{~L} \\
13 \mathrm{D}\end{array}$ & $\begin{array}{l}03 \mathrm{~L} \\
27 \mathrm{D}\end{array}$ & $30 \mathrm{D}$ & $30 \mathrm{D}$ & $30 \mathrm{D}$ & $30 \mathrm{D}$ \\
\hline Run 2 & $30 \mathrm{~L}$ & $\begin{array}{l}09 \mathrm{~L} \\
21 \mathrm{D}\end{array}$ & $\begin{array}{l}03 \mathrm{~L} \\
27 \mathrm{D}\end{array}$ & $30 \mathrm{D}$ & $30 \mathrm{D}$ & $30 \mathrm{D}$ & $30 \mathrm{D}$ \\
\hline Run 3 & $30 \mathrm{~L}$ & $\begin{array}{l}25 \mathrm{~L} \\
05 \mathrm{D}\end{array}$ & $\begin{array}{l}19 \mathrm{~L} \\
11 \mathrm{D}\end{array}$ & $\begin{array}{l}12 \mathrm{~L} \\
18 \mathrm{D}\end{array}$ & $\begin{array}{l}04 \mathrm{~L} \\
26 \mathrm{D}\end{array}$ & $\begin{array}{l}03 \mathrm{~L} \\
27 \mathrm{D}\end{array}$ & $\begin{array}{l}01 \mathrm{~L} \\
29 \mathrm{D}\end{array}$ \\
\hline Run 4 & $30 \mathrm{~L}$ & $\begin{array}{l}27 \mathrm{~L} \\
03 \mathrm{D}\end{array}$ & $\begin{array}{l}17 \mathrm{~L} \\
13 \mathrm{D}\end{array}$ & $\begin{array}{l}07 \mathrm{~L} \\
23 \mathrm{D}\end{array}$ & $\begin{array}{l}07 \mathrm{~L} \\
23 \mathrm{D}\end{array}$ & $\begin{array}{l}04 \mathrm{~L} \\
26 \mathrm{D}\end{array}$ & $\begin{array}{l}01 \mathrm{~L} \\
29 \mathrm{D}\end{array}$ \\
\hline Run 5 & $30 \mathrm{~L}$ & $\begin{array}{l}13 \mathrm{~L} \\
17 \mathrm{D}\end{array}$ & $\begin{array}{l}01 \mathrm{~L} \\
29 \mathrm{D}\end{array}$ & $30 \mathrm{D}$ & $30 \mathrm{D}$ & $30 \mathrm{D}$ & $30 \mathrm{D}$ \\
\hline Run 6 & $30 \mathrm{~L}$ & $\begin{array}{l}08 \mathrm{~L} \\
22 \mathrm{D}\end{array}$ & $30 \mathrm{D}$ & $30 \mathrm{D}$ & $30 \mathrm{D}$ & $30 \mathrm{D}$ & $30 \mathrm{D}$ \\
\hline Run 7 & $30 \mathrm{~L}$ & $\begin{array}{l}17 \mathrm{~L} \\
13 \mathrm{D}\end{array}$ & $\begin{array}{l}11 \mathrm{~L} \\
19 \mathrm{D}\end{array}$ & $\begin{array}{l}01 \mathrm{~L} \\
29 \mathrm{D}\end{array}$ & $30 \mathrm{D}$ & $30 \mathrm{D}$ & $30 \mathrm{D}$ \\
\hline Run 8 & $30 \mathrm{~L}$ & $\begin{array}{l}12 \mathrm{~L} \\
18 \mathrm{D}\end{array}$ & $\begin{array}{l}09 \mathrm{~L} \\
21 \mathrm{D}\end{array}$ & $\begin{array}{l}07 \mathrm{~L} \\
23 \mathrm{D}\end{array}$ & $\begin{array}{l}05 \mathrm{~L} \\
25 \mathrm{D}\end{array}$ & $30 \mathrm{D}$ & $30 \mathrm{D}$ \\
\hline $\begin{array}{l}\text { Mid } \\
\text { point }\end{array}$ & $30 \mathrm{~L}$ & $\begin{array}{l}04 \mathrm{~L} \\
26 \mathrm{D}\end{array}$ & $\begin{array}{l}02 \mathrm{~L} \\
28 \mathrm{D}\end{array}$ & $\begin{array}{l}01 \mathrm{~L} \\
29 \mathrm{D}\end{array}$ & $30 \mathrm{D}$ & $30 \mathrm{D}$ & $30 \mathrm{D}$ \\
\hline
\end{tabular}

L: Living L3 larvae

D: Dead L3 larvae 


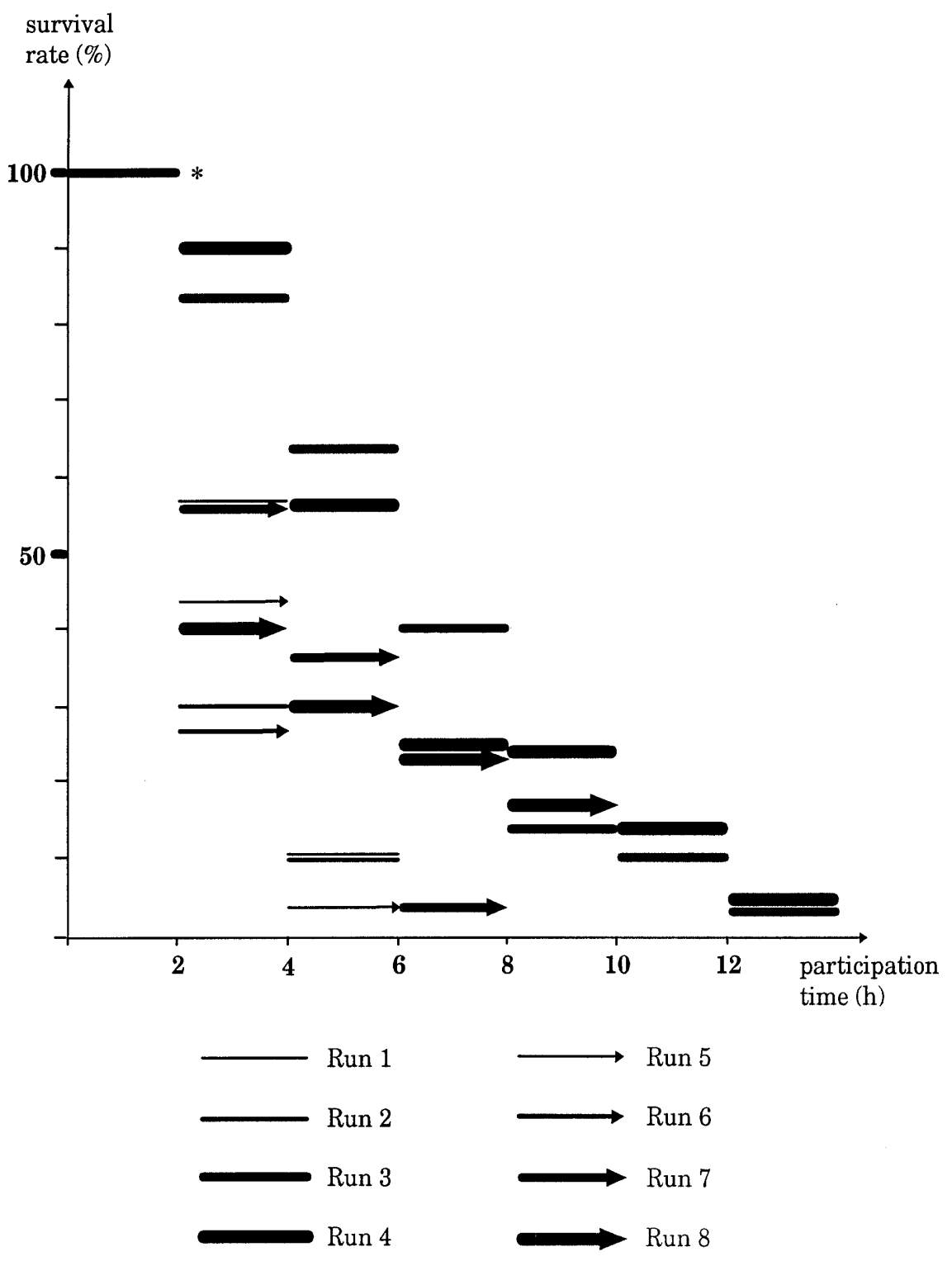

${ }^{*}$ All survival rates equal $100 \%$ between 0 and $2 \mathrm{~h}$

\section{Figure 2}

Survival curves of $30 \mathrm{~A}$. crassus L3 larvae in different runs, (see Table 1 for the design matrix).

\section{Figure 2}

Courbes de survie de $\mathbf{3 0}$ larves L3 d'Anguillicola crassus dans différents tests, (voir Tableau 1 pour l'organigramme des protocoles). 


\section{Table 3}

Evolution of the short-term survival rates for L3 A. crassus in digestive media.

\section{Tableau 3}

Evolution des taux de survie à court terme des larves L3 d'Anguillicola crassus dans les milieux de digestion.

\begin{tabular}{|c|c|c|}
\hline Run & $\begin{array}{l}\text { Survival } \\
\text { rate at } 2 h\end{array}$ & $\begin{array}{c}\text { Survival } \\
\text { rate at } 4 \mathrm{~h}\end{array}$ \\
\hline 1 & 0.567 & 0.100 \\
\hline 2 & 0.300 & 0.100 \\
\hline 3 & 0.833 & 0.633 \\
\hline 4 & 0.900 & 0.567 \\
\hline 5 & 0.433 & 0.033 \\
\hline 6 & 0.267 & 0.000 \\
\hline 7 & 0.567 & 0.367 \\
\hline 8 & 0.400 & 0.300 \\
\hline
\end{tabular}

Table 4

Survival rates: effects.

A : survival rate at $2 \mathrm{~h}$., B : survival rate at $4 \mathrm{~h}$.

\section{Tableau 4}

Taux de survie : effets.

$A$ : taux de survie à $2 h$., B : taux de survie à $4 h$.

A)

\begin{tabular}{|c|c|c|c|c|}
\cline { 2 - 5 } \multicolumn{1}{c|}{} & Average & $\begin{array}{c}\text { pepsin } \\
\text { concentration }\end{array}$ & pH & temperature \\
\hline Effect & 0.533 & -0.067 & $0.142^{*}$ & $-0.117^{*}$ \\
\hline
\end{tabular}

*significant effect at $5 \%$ (estimation of the experimental error after Goupy, 1988)

B)

\begin{tabular}{|c|c|c|c|c|}
\cline { 2 - 5 } \multicolumn{1}{c|}{} & Average & $\begin{array}{c}\text { pepsin } \\
\text { concentration }\end{array}$ & pH & temperature \\
\hline Effect & 0.263 & -0.021 & $0.204^{*}$ & $-0.088^{*}$ \\
\hline
\end{tabular}

*significant effect at $5 \%$ (estimation of the experimental error after Goupy, 1988) 
When comparing the survival curves by $\chi 2$ analysis (see Fig. 2 and Table 2), the survival time was longer at $20^{\circ} \mathrm{C}$ than at $30^{\circ} \mathrm{C}$ (comparison of the runs : 1-5, 2-6, 3-7 and 4-8) and at $\mathrm{pH}=1.8$ than $\mathrm{pH}=1.5$ (comparison of the runs $1-3,2-4,5-7,6-8$ ). At $\mathrm{pH}=$ 1.5 , high level of pepsin concentration lowered the survival time (comparison of the runs 1-2 and 5-6), whereas at $\mathrm{pH}=1.8$ pepsin appeared without influence on survival times (comparison of the overlapping of the curves 3-4 and 7-8).

\section{Flesh digestion}

The overall results are displayed in Table 5 and the main factors effects in Table 6.

Section (1) :

For small cut sections, a high level of pepsin and a high temperature favoured the hydrolysis while $\mathrm{pH}$ seemed without influence in the considered range.

Section (2) :

The effects of pepsin and temperature were similar to those described above. In this case, the main effect of the $\mathrm{pH}$ was closely related to the pepsin concentration effect.

Section (3) :

The addition of pepsin favoured the digestion process together with the elevation of temperature. The elevation of $\mathrm{pH}$ increased to a lesser extent the digestion.

In the three experiments, temperature and pepsin concentration were more «efficient» than $\mathrm{pH}$. The digestion was almost twice faster for sliced eel flesh pieces of 2$3 \mathrm{~g}$ (experiment 1).

\section{Table 5}

Digestion ratios after $12 \mathrm{~h}$.

\section{Tableau 5}

Taux de digestion après $12 \mathrm{~h}$.

\begin{tabular}{|c|c|c|c|}
\cline { 2 - 4 } \multicolumn{1}{c|}{} & Section (1) & Section (2) & Section (3) \\
\hline Run 1 & 35 & 4 & 6 \\
\hline Run 2 & 68 & 28 & 30 \\
\hline Run 3 & 23 & 11 & 14 \\
\hline Run 4 & 71 & 36 & 50 \\
\hline Run 5 & 77 & 36 & 52 \\
\hline Run 6 & 97 & 56 & 82 \\
\hline Run 7 & 58 & 42 & 54 \\
\hline Run 8 & 94 & 68 & 97 \\
\hline
\end{tabular}




\section{Table 6}

Effects of the factors in the three sections modalities.

\section{Tableau 6}

Effets des facteurs dans les trois types de sections.

Section (1) :

\begin{tabular}{|l|c|c|c|c|}
\cline { 2 - 5 } \multicolumn{1}{c|}{} & Average & $\begin{array}{c}\text { pepsin } \\
\text { concentration }\end{array}$ & $\mathbf{p H}$ & temperature \\
\hline Effect & 65.375 & $17.125^{\star}$ & -3.875 & $16.125^{\star}$ \\
\hline
\end{tabular}

* significant at $5 \%$ (estimation of the experimental error after Goupy, 1988)

Section (2) :

\begin{tabular}{|l|c|c|c|c|}
\cline { 2 - 5 } \multicolumn{1}{c|}{} & Average & $\begin{array}{c}\text { pepsin } \\
\text { concentration }\end{array}$ & $\mathbf{p H}$ & temperature \\
\hline Effect & 35.125 & $11.875^{*}$ & $10.375^{*}$ & $15.375^{*}$ \\
\hline
\end{tabular}

* significant at $5 \%$ (estimation of the experimental error after Goupy, 1988)

Section (3) :

\begin{tabular}{|l|c|c|c|c|}
\cline { 2 - 5 } \multicolumn{1}{c|}{} & Average & $\begin{array}{c}\text { pepsin } \\
\text { concentration }\end{array}$ & $\mathbf{p H}$ & temperature \\
\hline Effect & 48.125 & $16.625^{*}$ & $5.625^{\star}$ & $23.125^{*}$ \\
\hline
\end{tabular}

* significant at $5 \%$ (estimation of the experimental error after Goupy, 1988)

\section{DISCUSSION}

\section{Factors and experimental levels}

\section{Pepsin concentration}

Enzyme kinetics could not be applied in flesh digestion, since the substrate is not exclusively proteinic and its surface largely unknown. Only the volume of digestive solution versus the weight of substrate was quantified. Authors using enzymatic digestion procedures recommend the use of $1.2 \mathrm{ml}$ of medium per gram of substrate (HERLICH, 1956) or $2 \mathrm{ml} / \mathrm{g}$ (MINISTRY OF AGRICULTURE, FISHERIES AND FOOD, UK, 1971; EUZEBY, 1982). EUZEBY (1982) employed a 70 U.FIP/g pepsin to hydrolyse digestive tracts, in order to unhook the head of fixed Nematodes from the host. HUANG (1988, 1990) used a 2450 U.FIP/g pepsin to extract larvae of Anisakidae from the flesh of various fish species. The pepsin concentration mentioned in the literature varies greatly and figures range from $2.5 \mathrm{~g} / \mathrm{l}$ (STERN et al., 1958) to $40 \mathrm{~g} / \mathrm{l}$ (DEARDORFF et KENT, 1988).

In this study, 2500 U.FIP/g pig pepsin was used at concentration ranges between $2.5 \mathrm{~g} / \mathrm{l}$ and $40 \mathrm{~g} / \mathrm{l}$, with $2 \mathrm{ml} / \mathrm{g}$ of substrate.

$$
\text { pH }
$$

The effect of $\mathrm{pH}$ on survival of $A$. crassus $\mathrm{L} 2$ larvae in freshwater has been studied at $20^{\circ} \mathrm{C}$; the median survival time of these larvae varied between 150 and 60 days when $\mathrm{pH}$ varied between 4 and 9.2 respectively (KENNEDY et FITCH, 1990). In the absence of any available data of $\mathrm{pH}$ on the $\mathrm{L} 3$ larvae survival, this factor was controlled. Considering 
the activity of pepsin in relation to $\mathrm{pH}$ variation, our digestive media were set at $\mathrm{pH}=1.5$ or 1.8, close to the pH of optimum physiological activity of pig pepsin (GILBERG, 1988).

\section{Temperature}

The effect of temperature on survival of $A$. crassus $L 2$ larvae has been investigated by DE CHARLEROY et al., 1989, BONNEAU et al., 1991, and THIBAUT, 1992. In the range $12-41^{\circ} \mathrm{C}$, larval mortality increased with temperature.

Temperature also affects peptic digestion, optimal temperature being around $60^{\circ} \mathrm{C}$ (GILDBERG, 1988). Temperatures actually used in peptic digestion methods varied between $36-37^{\circ} \mathrm{C}$ (SCHWARTZ, 1939 ; HERLICH, 1956 ; CIORDIA et al., 1957 ; MINISTRY OF AGRICULTURE, FISHERIES AND FOOD, UK, 1971 ; GRABER et PERROTIN, 1983 ; BALLANTYNE et SAMUEL, 1984 ; HUANG, 1988, 1990) and $54^{\circ} \mathrm{C}$ (SMITH et WOOTTEN, 1975). Six of the eight references using $36-37^{\circ} \mathrm{C}$ were concerned with parasites of homeotherms ; the two others (HUANG, 1988, 1990) dealt with parasites of fishes. The internal temperature of a fish rarely exceeds $30^{\circ} \mathrm{C}$, a temperature used as the upper margin in this study as recommended by STERN et al. (1958). In a few L3 larvae exposed at $37^{\circ} \mathrm{C}$ in different media, mortality occurred almost instantaneously. The lower temperature has been set at $20^{\circ} \mathrm{C}$ : below this value, digestion times were considerably increased.

\section{Salinity}

DE CHARLEROY et al. (1989) found no significant differences on the survival of $A$. crassus L2, neither in freshwater nor in $1.5 \% \mathrm{NaCl}$ water. For KENNEDY et FITCH (1990), however, the longevity of these larvae was maximal at a $0.875 \% \mathrm{NaCl}$ concentration : $50 \%$ of the parasites survived up to 85 days at $10^{\circ} \mathrm{C}$, but only to 45 days in freshwater. Some authors recommended 0.85 to $0.90 \% \mathrm{NaCl}$ in the media, even when handling different Nematode species (HUANG, 1988, 1990 ; YOSHINAGA et al., 1989 ; DURAN et al., 1989). Moreover, $\mathrm{NaCl}$ was supposed to activate pepsin (GILDBERG, 1988 ; TROPEA et al., 1992). Therefore, in this study $0.875 \% \mathrm{NaCl}$ was added to the digestive media.

\section{Time for a complete digestion}

According to the size and shape of the organs or tissues to be digested, in relation to the concentration of pepsin and $\mathrm{HCl}$ and to the temperature, the time required for a complete digestion ranged from 15 minutes (STERN et al., 1958) to 24 hours (GRABER et PERROTIN, 1983). We limited our experiments to 12 hours.

\section{Effect of the various factors}

\section{Effect of pepsin concentration}

At $\mathrm{pH}=1.5$, a high concentration of pepsin was deleterious to $\mathrm{L} 3$ larvae. At $\mathrm{pH} 1.8$, pepsin was without influence on short-term survival. Living L3 larvae were protected from the action of pepsin by their cuticle, a broken cuticle leading invariably to a rapid destruction of internal structures. Whatever the section type, digestion ratios ranged between 4 and $97 \%$ and were higher in concentrated solutions. 


\section{Effect of $\mathrm{pH}$}

L3 larvae lived longer and digestion was more efficient at $\mathrm{pH}=1.8$ than $\mathrm{pH}=1.5$ For uncut flesh pieces (section 2), pH effect was as efficient as pepsin concentration (see Table 6).

\section{Effect of temperature}

Larval survival was lower at $30^{\circ} \mathrm{C}$ than at $20^{\circ} \mathrm{C}$ (see Table 2), confirming results of DE CHARLEROY et al. (1989), BONNEAU et al. (1991) and THIBAUT (1992). Whatever the section type, digestion was better at $30^{\circ} \mathrm{C}$ than at $20^{\circ} \mathrm{C}$.

\section{Effect of the type of section on digestion}

It was easy to verify that smaller pieces of fish were more completely digested than larger ones : comparison of the averages of percentage of digestion for sections (1) and (3), and that cuts in the flesh helped digestion : comparison of sections (1) and (2). Thus, to perform the method in accurate conditions, fishes should be dissected into $1 \mathrm{~g}$ pieces.

\section{Optimization : comparing larval survival and digestion}

A compromise had to be found between a high rate of L3 larvae survival and an efficient digestion : more larvae could be recovered at $30^{\circ} \mathrm{C}$, whereas at $20^{\circ} \mathrm{C} \mathrm{L3}$ larval survival was better. The optimal conditions for larval survival and flesh digestion were at $\mathrm{pH}=1.8$ According to GILDBERG (1988), $\mathrm{pH}=2-2.5$ could have provided a better hydrolysis. Nevertheless, the hydrolysis itself diluted the media with liquefied fish tissue, increasing the $\mathrm{pH}$. A buffer should be added, stabilizing the $\mathrm{pH}$ at 2-2.5 to improve digestion. For practical use, the highest concentration of pepsin should be employed considering its non significant effect on larval survival and its efficiency on flesh digestion.

\section{CONCLUSIONS}

Our initial goal, which was to recover living L3 larvae, had to be re-evaluated towards the recovery of dead but recognizable L3 stages.

The technique has been successfully employed in an epidemiological survey of the transmission of $A$. crassus on the fish species in Lake Grandlieu (BLANC, 1994). The optimal digestive medium contained $0.875 \% \mathrm{NaCl}, 10 \mathrm{~g} / \mathrm{l}$ pepsin and was at $\mathrm{pH}=1.8$ and ambient temperature $\left(20-22^{\circ} \mathrm{C}\right)$. Fishes were individually cut into small pieces, digested in a BAERMANN apparatus, allowing recovery of both living and dead L3 larvae after screening under a stereo-microscope. Almost all L3 larvae were recovered after 12 hours digestion and about half of them were alive. A few more L3 stages were found when the hydrolysis was carried out for 48 hours, not altering the epidemiological interpretation of the 12 hours digestion.

Different L3 survival rates have been observed during the epidemiological survey, for two probable reasons : (1) all larvae were not in contact with pepsin since the beginning of the experiment. Some of them, deep in the flesh, could be set free at the latter stage of digestion ; (2) the acidity of the digestive medium was altered by the digestion process, decreasing the enzymatic attack. 


\section{ACKNOWLEDGMENTS}

We would like to acknowledge helpful assistance from Dr Annie PETTER, Museum National d'Histoire Naturelle, Laboratoire de Biologie Parasitaire et Chimiothérapie, URA CNRS 114, 61 rue Buffon, 75231 Paris Cedex 05, France.

\section{REFERENCES}

ADAMS A.M., MILLER K.S., WEKELL M.M., DONG F.M., 1999. Survival of Anisakis simplex in microwave-processed arrowtooth flounder (Atheresthes stomias). J. Food Protection, 62, 403-409.

BALLANTYNE R.J., SAMUEL W.M., 1984. Diagnostic morphology of the third-stage larvae of three species of Parelaphostrongylus (Nematoda, Metastrongyloidea). J. Parasit., 70, 602-604.

BIRD A.F., 1957. Chemical composition of the nematode cuticle. Observations on individual layers and extracts from these layers in Ascaris lumbricoides cuticle. Experimental Parasitology, 6, 383-403.

BLANC G., 1994. Ecologie, biologie et contrôle thérapeutique des populations du parasite de l'anguille : Anguillicola crassus (Nematoda : Dracunculoidea). Thèse Univ. Perpignan, $367 \mathrm{p}$.

BONNEAU S., BLANC G., PETTER A.J., 1991. Etude sur la biologie des premiers stades larvaires d'Anguillicola crassus (Nematoda, Dracunculoidea) : spécificité de l'hôte intermédiaire et influence de la température sur la durée du développement. Bull. Fr. Pêche Piscic., 320, 1-6.

CHITWOOD B.G., 1936. Observations on the chemical nature of the cuticle of Ascaris lumbricoides var. suis. Proc. Helm. Soc. Wash., 3, 39-49.

CIORDIA H., VEGORS H.H., BIZZELL W.E., 1957. Freezing procedures for greater flexibility in application of the digestive method for post-mortem recovery of cattle nematodes. J. Parasit., 43, 532-534.

DE CHARLEROY D., THOMAS K., BELPAIRE C., OLLEVIER F., 1989. The viability of the free living larvae of Anguillicola crassus. J. Appl. Ichthyol., 5, 154-156.

DEARDORFF T.L., KENT M.L., 1989. Prevalence of larval Anisakis simplex in penreared and wild-caught salmon (Salmonidae) from Puget Sound, Washington. J.Wildlife Diseases, 25, 416-419.

DEARDORFF T.L., THROM R., 1988. Commercial blast-freezing of third-stage Anisakis simplex larvae encapsuled in salmon and rockfish. J. Parasit., 74, 600-603.

DURAN S.M.L., QUINTEIRO P., UBEIRA F.M., 1989. Nematode parasites of commercially important fish in NW Spain. Dis. aquat. Org., 7, 75-77.

EUZEBY J., 1982. Diagnostic expérimental des helminthoses animales (animaux domestiques - animaux de laboratoire - primates). Travaux pratiques d'helminthologie vétérinaire. Livre 2 : diagnostic direct post mortem, diagnostic indirect (diagnostic biologique), France, $364 \mathrm{p}$.

GILDBERG A., 1988. Aspartic proteinases in fishes and aquatic invertebrates. Comp. Biochem. Physiol., 91B, 425-435.

GOUPY J., 1988. La méthode des plans d'expériences. ed. Dunod, France, 300 p.

GRABER M., PERROTIN C., 1983. Helminthes et helminthoses des ruminants domestiques d'Afrique tropicale. Institut d'Elevage et de Médecine Vétérinaire des Pays Tropicaux. Editions du Point Vétérinaire, Maisons-Alfort, France, 378 p.

HERLICH H., 1956. A digestion method for post-mortem recovery of nematodes from ruminants. Proc. Helm. Soc. Wash., 23, 102-103.

HUANG W., 1988. Anisakidés et anisakidoses humaines. Deuxième partie : enquête sur les Anisakidés de poissons commerciaux du marché parisien. Ann. Parasitol. Hum. Comp., 63, 197-208. 
HUANG W., 1990. Méthodes de recherche des larves d'Anisakidés dans les poissons marins. Possibilités d'application à l'inspection des poissons commercialisés en région parisienne. Rec. Méd. Vét., 166, 895-900.

KENNEDY C.R., FITCH D.J., 1990. Colonization, larval survival and epidemiology of the nematode Anguillicola crassus, parasitic in the eel, Anguilla anguilla, in Britain. J. Fish Biol., 36, 117-131.

LAPLANCHE A., COM-NOUGUE C., FLAMANT R., 1987. Méthodes statistiques appliquées à la recherche clinique. Collection Statistique en Biologie et en Médecine. Médecine-Sciences Flammarion, France, 168 p.

MANTEL N., 1966. Evaluation of survival data and two new rank order statistics arising in its consideration. Cancer Chemotherapy Reports, 50, 163-170.

MINISTRY OF AGRICULTURE, FISHERIES AND FOOD, 1971. Manual of veterinary parasitological laboratory techniques. Technical Bulletin №18. Her Majesty's Stationery Office, London, England, $131 \mathrm{p}$.

PETTER A., FONTAINE Y.A., LE BELLE N., 1989. Etude du développement larvaire d'Anguillicola crassus (Dracunculoidea, Nematoda) chez un Cyclopidae de la région parisienne. Ann. Parasitol. Hum. Comp., 64, 347-355.

PLATT T.R., 1989. Gastropod intermediate hosts of Parelaphostrongylus tenuis (Nematoda : Metastrongyloidea) from northwestern Indiana. J. Parasit., 75, 519523.

POLITZ S.M., PHILIPP M., 1992. Caenorhabditis elegans as a model for parasitic nematodes : a focus on the cuticle. Parasitology Today, 8, 6-12.

REINECKE R.K., BROOKER D., 1972. Recovery of parasitic nematodes from the gastrointestinal tract of a mule at autopsy. Onderstepoort J. vet. Res., 39, 51-58.

REINEMEYER C.R., HERD R.P., 1986. Comparison of two techniques for quantitation of encysted cyathostome larvae in the horse. Am. J. Vet. Res., 47, 507-509.

SCHWARTZ B., 1939. Freedom from viable trichinae of francfurters prepared under Federal meat inspection. Proc. Helm. Soc. Wash., 6, 35-37.

SMITH J.W., WOOTTEN R., 1975. Experimental studies on the migration of Anisakis sp. larvae (Nematoda : Ascaridida) into the flesh of herring, Clupea harengus $\mathrm{L}$. International J. Parasitol., 5, 133-136.

SPRENT J.F.A., 1952. On the migratory behavior of the larvae of various Ascaris species in white mice. J. Inf. Diseases, 90, 165-176.

STERN J.A., CHAKRAVERTI D., UZMANN J.R., HESSELHOLD M.N., 1958. Rapid counting of nematoda in Salmon by peptic digestion. United States Fish and Wildlife Special Scientific Report, $n^{\circ} 255,5 \mathrm{p}$.

THIBAUT D., 1992. Etude de la morphologie et de la biologie des stades libre et infestant d'Anguillicola crassus (Nematoda, Dracunculoidea) parasite de l'anguille européenne (Anguilla anguilla L. 1758). Th. Doc. Vét., Univ. Nantes, 132 p.

TROPEA J.E., NASHED N.T., LOUIS J.M., SAYER J.M., JERINA D.M., 1992. Effect of salt on the kinetic parameters of retroviral and mammalian aspartic acid proteases. Bioorganic chemistry, 20, 67-76.

VIGNAU M.L., DEL VALLE GUARDIS M., RISSO M.A., EIRAS D.F., 1997. Comparison between two methods for diagnosis of trichinellosis : trichinoscopy and artificial digestion. Mem. Instit. Oswaldo Cruz, 92, 585-587.

YOSHINAGA T., OGAWA K., WAKABAYASHI H., 1989. Life cycle of Hysterothylacium haze (Nematoda : Anisakidae : Raphidascaridinae). J. Parasit., 75, 756-763. 